\title{
R. J. FITCH, 1886-1961
}

CHARLES D. BIRD, Dept. of Biology, Univ. of Calgary, Calgary, Alberta T2N $1 \mathrm{~N}$

One of seven brothers, Richard John Fitch was born in 1886 . The son of Edward A. Fitch, who at one time served as President of the British Entomological Society, "Dick" began collecting British Lepidoptera as a young boy. After finishing his schooling, he worked for Lloyd's of London. The west soon began to lure him, however, and in 1905, at the age of 20, he left Malden, Essex for Canada.

He homesteaded 16 miles south and two miles west of the town of Lloydminster. His first Alberta home was a shack. The home quarter, with Blackfoot Coulee and a large gully running through it, was a prime location for collecting but Dick was so busy proving up the land and making the farm a going economic unit that he was forced to forget his hobby interest until later in life.

In 1917, Dick married Dorothy Isobel Atkinson. "Dolly", who was 14 years younger than her husband, came out from Ripley, Derbyshire, England with her parents in 1912. Her first Alberta home was a sod house.

Dick was a big man and physically active. He won a number of prizes for his prowess at swimming and he played soccer and cricket. He even built a tennis court on the farm. Work in the early days was physically demanding and it was some time before he was able to supplant horse power by tractor power. He had a large stamp collection and was frequently called upon to act as an auditor.

Dick started collecting again in 1921. His wife made him a net out of a slender willow, an old broom handle and a piece of cheese cloth. A local druggist helped by making him a cyanide bottle. Farm activities $k$ him close to home but that did stop him from collecting. He regul. took his net and bottle to the $\mathrm{fi}$ Butterflies were more numerous in early days as there were still $m$ areas of native prairie.

By 1930 he was collecting in earn often helped by his wife and child and this activity continued until retired from the farm. He began correspond with people in the $f$ and by 1940 was in touch with $m$ museums and individuals in $\mathrm{Nc}$ America and England. He develope small business in which he specimens, often for a dollar each sometimes even for more. From 1 to 1956 he distributed a hand-con list entitled "List of Arctic specie Lepidoptera caught by R. J. Fitch Lloydminster, Saskatchew Canada". Although his main inte was in butterflies, he also colled and sold moths which he captured night with the aid of a light and using sugared bait.

Specimens for sale or exchange $n$ placed in paper triangles folded $f_{1}$ magazine pages and were then sto or mailed in $1 / 2$ pound tobacco $c$; To begin with he simply put the spe name, "Fitch", the date of collect and "Lloydminster" on the pack This created some confusion as it not clear from which province insects had originated. J. H. Mast for example, in his paper "R. J. Fit List of Saskatchewan Butterfl which appeared in 1968 in the Blue (26:194-199) states "there is evidence that Fitch collected to extent in Alberta".

Correspondence with Fitch's wic and other members of his fam 


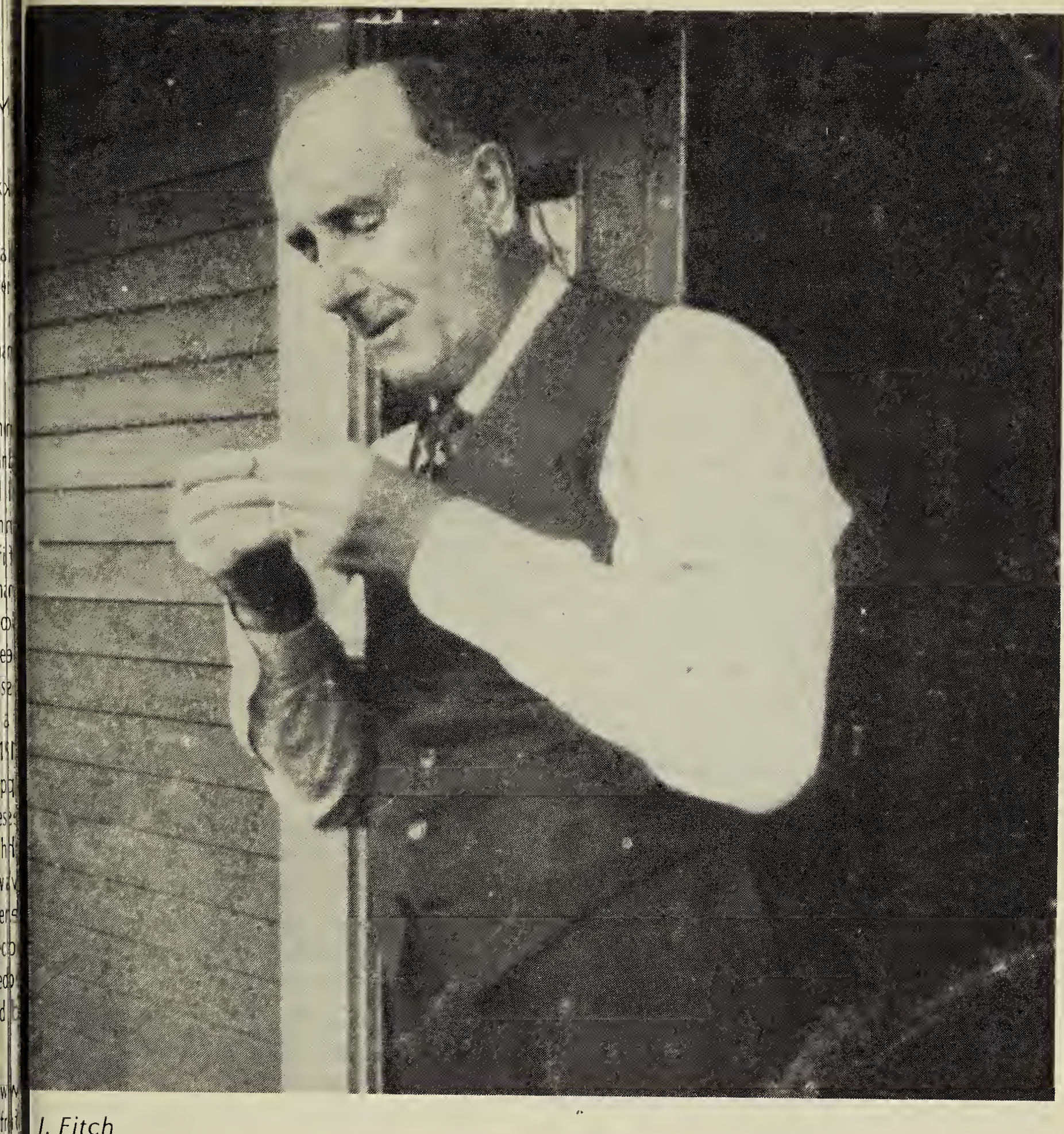

Dwever, reveal that the original mestead was on the southwest larter of section 14, township 47, nge 1 , west of the fourth meridian. nce the fourth meridian is the 110th rallel of longitude and also forms Alberta-Saskatchewan boundary, farm was between $11 / 2$ and 2 miles ide Alberta. Although the town of pydminster is partly in Alberta and rtly in Saskatchewan, literally addling the boundary, the Lloydnster post office is in Saskatchewan. though Fitch got his mail in the hamlet of Rivercourse two miles west of the boundary, the address was not given as Rivercourse, Alberta, but as Rivercourse via Lloydminster, Saskatchewan. No wonder that confusion resulted!

The family report that most of Fitch's material was collected on or close to his farm, two miles north of Rivercourse, Alberta. A few collections were also made in the Blackfoot hills, a few miles to the northwest of the farm and slightly further into Alberta, 
and along the Battle River, about 13 miles south of the farm, reached by a road one mile west of the boundary. These Alberta collections were in the Aspen Parkland and here he captured insects typical of the prairies and aspen groves.

The only area in Saskatchewan where he collected was on the Fifield farm near Harlan, a rural post office 25 miles north and 3 miles east of the boundary. This area is in the Boreal Forest and his material from there is characteristic of coniferous forest, .muskeg, and bogs.

Fitch gave up farming in 1942, bought a house in Vancouver, and moved there with his wife. For a number of years he spent the winter at the coast and the summers back on the farm where he was able to continue his collecting activities. He died in 1961 at the age of 78 and was buried at Vancouver. His personal collection, stored in a number of boxes, was divided among his family after his death.

R. J. Fitch was survived by his wife at Lloydminster; sons Ted, on the original farm near Rivercourse, and Tom, of Edmonton; daughters Eva, Isobel and Cicely of McLaughlin, the next hamlet southwest of Rivercourse, Alberta, and Peggy of Lloydminster; 15 grandchildren and 20 great-grandchildren.

\section{A TRIBUTE TO \\ "CORKY" JONES OF EASTEND}

The death of "Corky" Jones on March 27, 1978 at the age of 97 terminated a remarkably fruitful association with southwestern Saskatchewan. In the CBC "Neighborly News from the Prairies" programme on May 28, Fred McGuiness of Brandon used the Eastend Enterprise's editorial salute to the memory of $\mathrm{H}$. S. Jones and his unusual contribution to th development of the Western Plains. Wit Mr. McGuiness' permission, we quote th tribute.

"Corky" Jones to me is an exampl of one of those Prairie pioneers who spirit and in deed built the West an gave the West its flavor. While $h$ father was a physician to Quee Victoria, Corky had no suc aspirations: he wanted to see the $\mathrm{Ne}$ World. For many years he was cowboy and then a rancher aroun Maple Creek. From the Metis familis nearby he learned of their history, an human history led him into a chaeology as a highly talente amateur. Retired from ranching he ra a livery stable, then the first electr light plant, but no matter what his jol he was collecting archaeologic specimens which he developed into museum, now located in Eastend Hig School.

In his book Wolf Willow, whi should be read by every Prair resident, Wallace Stegner says: "If community is really a pile of kindlin inert and heatless until some accide of heat or some man touches it wi fire, then Corky in his humble al unpretentious way is a sort of lig bringer."When Corky Jones was tow night watchman, ringing the curfe each night at nine, he was maki discoveries which set the world archaeology a-buzzing. One of discoveries, the skull of the dinosa called ceratopsian is unique: no simi one has been found in this world.

Corky Jones died at the age of and the Eastend Enterprise describ him as a man who had been educator without salary for the grea part of his life. This tribute is writt by Elsie Bock, and with a name li that, she just has to be a kin to $\mathrm{Bi}$ Bock, author, poet, composi philosopher, one-time member Parliament for that colorful short gra rangeland. 